49 Hylander WL (1988) Implications of in vivo experiments for interpreting the functional significance of "robust" australopithecine jaws. In Grine FE (ed), Evolutionary History of the Robust Australopithecines, pp 55-83. New York: Aldine de Gruyter.

50 Demes B, Preuschoft H, Wolff JEA (1984) Stress-strength relationships in the mandibles of hominoids. In Chivers DJ, Wood BA, Bilsborough A (eds), Food Acquisition and Processing in Primates, pp 369-390. New York: Plenum.

51 Ravosa MJ (1991) Structural allometry of the prosimian mandibular corpus and symphysis. J Human Evol 20:3-20.

52 Daegling DJ (1992) Mandibular morphology and diet in the genus Cebus. Int J Primatol, in press.

53 Weijs WJ (1989) The functional significance of morphological variation of the human mandible and masticatory muscles. Acta Morphol Neerl Scand 27:149-162.

54 Umetani Y, Inou M (1988) Movement and function of mandible-a simplified mechanico-morphological model of mandible. Anat Anz 165:193-196.
55 Dechow PC, Nail GA, Ashman RB (1989) A comparison of the elastic properties of mandibular bone in rhesus monkeys and humans Am J Phys Anthropol 78:211.

56 Dechow PC, Schwartz-Dabney C, Ashman RB (1991) Regional variation of mechanical properties in the human mandibular symphysis. Am J Phys Anthropol Suppl 12:66.

57 Wolpoff MH (1975) Some aspects of human mandibular evolution. In McNamara JA Jr. (ed), Determinants of Mandibular Form and Growth. Monograph \#4, Craniofacial Growth Series, pp 1-14. Ann Arbor: Center for Human Growth and Development, University of Michigan.

58 Hooton EA (1946) Up from the Ape. New York: Macmillan.

59 Laitman JT, Heimbuch RC (1982) The basicranium of Plio-Pleistocene hominids as an indicator of their upper respiratory systems. Am J Phys Anthropol 59:323-343.

60 Smith RJ (1984) Comparative functional morphology of maximum mandibular opening (gape) in primates. In Chivers DJ, Wood BA, Bilsborough A (eds) Food Acquisition and Processing in Primates, pp 231-255. New York:
Plenum.

61 Rudwick MJS (1964) The inference of function from structure in fossils. Br J Philos Sci 15:27-40.

62 Mayr E (1983) How to carry out the adaptationist program? Am Nat 121:324-334.

63 Weijs WA (1980) Biomechanical models and the analysis of form: A study of the mammalian masticatory apparatus. Am Zool 20:707-719.

64 Smith RJ (1982) On the mechanical reduction of functional morphology. $J$ Theor Biol 96:99-106.

65 Liem KF, Wake DB (1985) Morphology: Current approaches and concepts. In Hildebrand M, Bramble DM, Liem KF, Wake DB (eds), Functional Vertebrate Morphology, pp 366-377. Cambridge, MA: Belknap.

66 O'Grady RT (1986) Historical processes, evolutionary explanations, and problems with teleology. Can J Zool 64:1010-1020.

(C) 1993 Wiley-Liss, Inc.

\title{
Ecological Demography: A Synthetic Focus in Evolutionary Anthropology
}

\author{
BOBBI S. LOW
}

The interests of evolutionary anthropologists, behavioral ecologists, and demographers converge on the ecology of human fertility. Ecological conditions influence the optimum pattern of maternal effort. Patterns of abortion, neglect, and infanticide vary with mothers' ability to invest in their children and children's ability to use that investment. As in most other mammals, the ecology of human fertility varies between the sexes: status and resource control are important for males, whereas reproductive value is crucial for females. In pre-industrial societies, and even in monogamous societies in demographic transition, wealthy men had more children than did poorer men. This correlation, often assumed to have disappeared, persists today, with richer men still having more sexual access than others. Sex differences in the ecology of fertility mean that sex of the offspring, as well as birth order, influences parental investment. Because individual fertility varies with environment, it is not surprising that "natural" (uncontrolled) fertility varies across societies or that demographic transitions proceed locally, with occasional reverses, as individuals strive to maximize their lifetime reproductive success in changing, competitive, conditions.

Bobbi S. Low is Professor of Resource Ecology in the School of Natural Resources and Environment, University of Michigan. Originally trained in evolutionary and behavioral ecology, she currently works on human resource ecology.

Key words: Demography, fertility, population, life history, demographic transition
Anthropologists, biologists, and demographers are all interested in human reproductive patterns, sex differences, and ecological correlates of behavior-in the life histories of humans. The underlying paradigms they use can differ significantly. Classical demographers study population patterns, whereas historical demogra- phers approach human populations in a manner more like that of anthropologists and biologists, seeking family patterns and population shifts that correlate with external conditions such as economic fluctuations. ${ }^{1}$ I agree with Watkins ${ }^{2}$ that any "satisfactory theory of fertility change has to explain differences in the onset and pace of fertility declines as well as fluctuations in fertility." ( p. 28). Yet classical demographic transition theory has not proved especially helpful. Demographic correlations vary in time and space far more than one would expect them to ${ }^{3,4}$ if the correlations represented universal principles. As Schofield and Coleman ${ }^{5}$ noted, "Any subject which finds it necessary, or indeed possible, to consider its material divorced from an appropriate body of theory must be in trouble" (p. 5).

Humans, of course, are not the only species in which fertility varies. For other species, the predictive ecologi- 
cal rules are relatively clear, although they have not always been quantified. The power and predictive ability of models of fertility onset and fluctuation for other species derive from life history theory in behavioral ecology. ${ }^{6-}$ ${ }^{10}$ Ecological demography arises from two facts: that the reproductive behavior of humans, like that of other species, is influenced by natural selection and that current fitness is the product of both genotype and environment. ${ }^{11-}$ ${ }^{13}$ Here I review classic atheoretical and recent theoretical studies that contribute to this emerging field, exploring the extent to which human reproductive responses to ecological conditions, considered in their broadest context, follow the same selective rules as other species.

\section{NEW PERSPECTIVES}

Ecological demography begins with the proposition that demographic patterns, observed at the population level, arise from individuals striving to maximize their successful lifetime reproduction. Genetics, cultural transmission, and the environment interact to produce a sometimes changing set of reproductive strategies. Individuals within a population may experience different environments; therefore, optimal reproductive strategies can differ not only over time, but within subgroups of a population as well. Ecological demography primarily differs from classic demography in its focus on ultimate versus proximate "causes," its focus on individual versus group costs and benefits, and its recognition that the reproductive ecology of males and females frequently differs. As a result of these differences, it uses measures that are based on individuals rather than on populations.

\section{Level of Causality}

Many demographic analyses involve what evolutionary anthropologists call proximate triggers. For example, we may discover that, in a particular society, men who marry younger women have more children in their lifetimes than do men who marry older women or that younger women command a higher bride price than do older ones. One can ask why such patterns exist at several levels. The ultimate cause of a behavior's evolution is always its impact on the persistence of a genetic lineage through survival and reproduction. Many quite different proximate mechanisms may come into play because they enhance survival and reproduction. When we wish

\section{Individuals within a population may experience different environments; therefore, optimal reproductive strategies can differ not only over time, but within subgroups of a population as well. Ecological demography primarily differs from classic demography in its focus on ultimate versus proximate "causes," its focus on individual versus group costs and benefits, and its recognition that the reproductive ecology of males and females frequently differs.}

to understand whether a behavior is a functional evolutionary response, the study of trait-environment correlations-of ultimate function-takes precedence. Elucidating proximate mechanisms can enrich our understanding. What mechanisms are useful depends on salient features in the external environment and on whatever internal devices already exist in the organism. For example, fertility declines are predicted to occur as a functional evolutionary response in humans, as in other species, when parental effort enhances offspring success sufficiently to compensate for the lost numbers. ${ }^{14}$ Different proximate mechanisms can cause fertility to decline: later age at marriage, longer interbirth intervals, earlier "stopping." When, as in medicine or family planning, our primary concern is intervention, ${ }^{15}$ the particular mechanism becomes important.

\section{Levels of Selection}

Clearly, the only behaviors that can evolve by natural selection are ones that enhance the success of a genetic lineage. Such behaviors are selfish, parental, reciprocal, or helpful to relatives, and therefore enhance inclusive fitness. Genetic altruists-those who, to their cost and others' benefit, restrict or cease reproduction-decline in the population, being replaced by individuals who, as Darwin himself recognized, behave to their own reproductive benefit. ${ }^{16}$ Thus there is no evidence of evolved homeostatic population regulation mechanisms (contra refs. 14,17,18). If the function of fertility shifts were, in fact, to regulate population, pre- and posttransition societies might often seek to achieve this regulation through imposed infertility. From a population point of view, nothing would inhibit enforced infertility to regulate population, ${ }^{14}$ yet societies "do not favor childlessness." 19 Indeed, attempts to regulate individual fertility for the good of the group (for example, China's recent "one child" policy) engender fierce opposition.

Genetic selfishness still produces apparent population responses to resource levels as an emergent phenomenon. This occurs because many families, differing in their resources, attempt to optimize their fertility in varying conditions, and subgroups impose legal or religious coercion. These two fertility responses are functionally quite different. The extent to which restrictions impose costly constraints on individual optimization may predict the extent to which individuals will resist them. It would be rewarding to explore empirically when fertility shifts arise from "ordinary" selection-when, for example, having fewer children results in more living descendants for individuals, versus coalition-imposed fertility shifts. Recently Hawkes and Charnov ${ }^{20}$ have summarized the argu- 
ments cogently in anthropology (see also Botkin ${ }^{21}$ ).

\section{Sex Differences}

When women's and men's lives are compared, some reproductive patterns must, of course, be similar. For example, the average number of children can never be higher for women than for men. Other phenomena, such as age at marriage, variance in reproductive success, and the rate and impact of remarriage, can differ strikingly between men and women.

Some of these differences arise simply from the fact that we are mammals. Other things being equal, male mammals achieve maximum reproductive success by expending their reproductive effort as mating, rather than parental effort, and by making a generalized parental effort ${ }^{22,23}$ rather than a truly offspring-specific parental investment. ${ }^{24}$ Female mammals, equipped to nurse their young, do best by producing healthy, viable offspring, and apportioning their effort among specific offspring.

The principal difference between these expenditure patterns is that mating effort and parental effort that is not offspring-specific, unlike true parental investment, may have a high fixed cost: much must be spent before any success is realized (Fig. 1A). Furthermore, later successes cost little compared to the cost of the first success. Thus, although many males will fail to reproduce, a successful male may have many times more offspring than the most successful female. ${ }^{25,26}$ This has profound implications with regard to risk-taking and survival in males versus females. As a result, within polygynous species (including humans, whose evolutionary background is polygynous), males typically survive less well than females (Fig. 1B). This sex difference has further implications for parents: optimal parental expenditure may not mean equal investment in the two sexes.

\section{New Measures}

Aggregate demographic measures are inappropriate for many behavioral ecologists' questions because they vary with the relative representation of subgroups. Further, intragroup variation is not reflected in aggregate statistics, making differences between populations or between groups within a population difficult to assess.

Behavioral ecological studies typically measure some form of lifetime success: matings, births, numbers of offspring reaching independence, or numbers of grandchildren. Recent studies on human $s^{27-40}$ have measured actual lifetime fertility in the behavioral ecological tradition, using measures analogous to the demographers' net reproductive rate (NRR), which calculates the number of daughters expected if all females have mean agespecific fertility and mortality. ${ }^{41}$ However, the new measures are based on individual patterns, carry variances, and consider children of both sexes. Studies may also measure within-family survivorship and the mortality rates of children, as well as the number of children alive at some specified age. Measures of children reaching independence reflect the "net success" for parents resulting from the interaction of other measures: survival to maturity, probability of marrying, age at marriage, age at birth of first child, marital fertility rate, child survival, lactational infecundity, and so forth. Predictions from "biological" and standard demographic measures differ. ${ }^{37}$ When lifetime reproductive patterns, sex differences, or variation in behavior are important, these "biological" measures are probably more accurate and yield more information than do standard demographic measures.

\section{THE ECOLOGY OF FERTILITY}

Ecological demography considers relationships that might never interest classical demographers. Because population patterns arise as an incidental side effect of individual patterns, rather than as evolved phenomena themselves, ecological demography examines not only the obvious correlations between population and environment (e.g., marriage rate, marital fertility, and cost of living), but individual reproductive costs and benefits. These can include such considerations as mothers' ability to invest in their children, as affected by these women's age, health, nutritional status, marital status, and the length of time since they last gave birth. At-
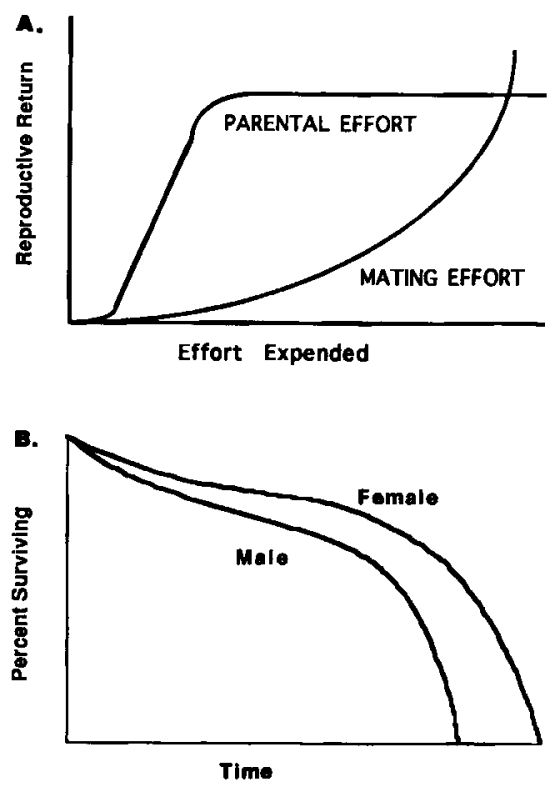

Figure 1. (A) Mating and parental effort have markedly different return curves. Obtaining even a single mate frequently requires great initial effort and expenditure (a high fixed cost). For example, a male red deer may need to wait an extra few years to grow big enough to compete with territorial males, grow antlers. and fight for territory, all to win even a single mate, Investing in offspring (parental effort), however, is typified by a different pattern: there is a level of investment below which the offspring cannot survive and reproduce: above that amount, the offspring's chances improve, but there is a limit on the amount of investment that will improve the offspring's chances. 117 Thus, in any species or in any human society in which males specialize in mating effort and females in parental effort, extremely different behaviors will characterize the two sexes. (B) As a result of these return curves, males will tend to be risk-takers; females will tend to be riskaverse. Reproductive failure will be higher and survival lower among males.

tention might also focus on the desirability of marital partners as influenced, for men, by wealth, land ownership, or occupation and for women, by reproductive value and health. Another subject of interest might be the probable success of a particular child as a consequence of intrinsic factors such as child health and sex, and extrinsic factors such as economics, the worth of other children, and reproductive value.

The costs and benefits of any particular reproductive event differ for men and women of different age, occupation, wealth, and health, and lead to different patterns within populations, depending on the composition of individuals, environmental richness, evenness, and predictability. Let us review, then, individual responses 
to ecological conditions that can result in correlations between ecological conditions and fertility patterns. These responses can be physiological or social; those that are social may or may not involve conscious decisions.

\section{Male Cultural and Reproductive Success: The Importance of Resource Value}

When resource-controlling men can have higher fertility than others-for example, through polygyny in bride-price societies-fertility tends to be high, but variable. Such conditions obtain in many traditional societies and some pre- and proto-industrial societies. ${ }^{42,43}$ In quite varied societies, wealth or status correlates positively with men's reproductive success. ${ }^{29}$ Richer Turkmen were found to have more wives and children than poorer men. ${ }^{27}$ In the pastoral Mukogodo of Kenya, wealth also enhances men's reproductive success. ${ }^{44}$ Similarly, among the Meru, who use livestock for bridewealth, richer men can marry more wives. ${ }^{45}$ In societies as diverse as the Hausa, ${ }^{46}$ Trinidadians ${ }^{47}$, and Micronesian islanders, ${ }^{48}$ status and wealth correlate with male reproductive success.

In some societies, such as the Ache $^{49,50}$ and the Yanomarnö, ${ }^{51-53}$ few physical resources are owned, but even here, status represents a resource. Among the Ache, not only do men who are good hunters mate more often than other men, but their children survive better. ${ }^{50}$ Among the Yanomamö, male kin available for coalitions also represent a resource. The men manipulate kinship terms in ways that make more women available for mating, and render powerful men available as coalition partners, ${ }^{51,52}$ so that reproductive success is uneven. In this population, the most successful methods of gaining wives are belonging to a powerful kin group and gaining recognition as a revengekiller. ${ }^{53}$ Among the polyandrous Toda, a man's centrality in the kinship network is related to his reproductive success. ${ }^{54}$

These patterns are consistent with the behavioral ecological hypothesis that resources contribute to reproductive success, ${ }^{34,35,38}$ but are not consistent with the demographic hypothesis regarding children as resources and producers..$^{55}$ If parents perceive children as producers in agricultural work, then both land workers and land owners should have high fertility. Yet land owners typically have higher fer-

\section{In quite varied societies, wealth or status correlates posifively with men's reproductive success. Richer Turkmen were found to have more wives and children than poorer men.}

tility and, consequently, larger families than land workers no matter what the economic weather. In addition, family size varies, less among owners than workers. ${ }^{37,42,43,56-60}$ Land ownership apparently provides a more reliable resource control, a buffer against hard times.

The positive correlation between resources and lifetime reproductive success holds through demographic transition..$^{38}$ Results from contemporary societies are mixed.${ }^{14}$ As Low and Clarke $^{38}$ note, studies using proxy measures rather than actual resource control often yield negative results. This is true, for example, of a study by Birdsall, ${ }^{61}$ which used total fertility rate (TFR) and gross national product (GNP), both population measures, and of a study by Vining, ${ }^{62}$ which used individual education and intelligence quotients. Studies that examine lineages, ${ }^{63}$ individual patterns, ${ }^{64}$ and some census data ${ }^{65}$ tend to produce positive results. Today, contraception technology complicates the issue; but when sexual access, rather than fertility, is measured, richer men clearly have more sexual access than do poorer men. ${ }^{66}$

\section{Bride Age: The Importance of Reproductive Value}

Keyfitz $^{68}$ used Fisher's ${ }^{67}$ concept of reproductive value to make predictions about migration, contraception, and population growth. That concept is also useful in understanding trends in marriage age and remarriage rates. Reproductive value, derived from agespecific fertility and mortality rates, is defined as the probable number of daughters a woman will have during the rest of her life, thus encompassing age-specific fertility and survivorship functions. Thus, in societies with a bride price or other exchange of goods at marriage, ${ }^{69}$ young women might be expected to command the highest bride prices. If high reproductive value is seen as desirable, men with great economic resources may be able to command women with high reproductive value. Another way of putting it is that women with high reproductive value are free to choose men with greater resources, although direct female choice is difficult to demonstrate in many societies. Among the agricultural and pastoral Kipsigis, the bride price required for a woman was directly related to her reproductive value. ${ }^{30,32}$ With the introduction of western technology and medicine, differentials were reduced.

Poor men might choose to marry older women with greater resources when they can, explicitly trading reproductive value for resource value. Thus in eighteenth and nineteenth century Scandinavia, daughters of upper-middle-class men, who would marry relatively richer men, were considered to be marriageable at the age of eighteen years, whereas daughters of poorer men, who would marry poorer men, were not considered marriageable until they reached their midto-late twenties. ${ }^{36,70}$ Richer men, in marrying younger women, gained high reproductive value, but also provided resources. Hughes ${ }^{59}$ found similar patterns with regard to men's wealth and women's reproductive value in Lancashire, England.

\section{Remarriage for Widows and Widowers}

In most societies, widows commonly remarry far less frequently than widowers, a fact that has no obvious demographic or economic explanation. Further, women remarry at earlier ages than do men, and women's probability of remarriage declines with age. Classical demographers ${ }^{71,72}$ 
have found such patterns puzzling, for women's economic value, like men's, does not decline with age. Nevertheless, women's reproductive value does decline. Furthermore, the decline from peak reproductive value is a certainty, in contrast to the risk of death, which causes lower-than-peak reproductive value at early ages.

Not surprisingly, when men remarry they tend to marry women who are younger than themselves and have high value. This undoubtedly contributes to the fact that men's second marriages are more fertile than are women's, even in societies with late ages at first marriage and socially imposed monogamy. Although in many societies the pattern can be slightly modified by the operant sex ratio, ${ }^{73}$ the patterns are quite strong: widows remarry far less frequently than widowers; ${ }^{73-79}$ widows with dependent children remarry at an even lower rate; ${ }^{74,78-80}$ and widows commonly do not remarry at all when they are older. ${ }^{77}$ In contemporary society these patterns also persist. ${ }^{81,82}$

\section{Optimization of Maternal Effort}

Variation in fertility reflects the fact that maternal investment in one child may occur at the expense of investment in others. ${ }^{24}$ Closely spaced pregnancies, when nutrition or other factors are limiting, may result in lowered lifetime reproduction. Today, a clearly negative correlation exists between a mother's job status or education and her lifetime fertility. ${ }^{15}$ This implies a conflict: what is invested in work cannot be invested in child care. In traditional societies, too, there exist problems of optimizing maternal effort, even at the physiological level. Bailey et al. ${ }^{85,86}$ have found that Efe women's ovarian function and resulting birth schedules follow a seasonal pattern that correlates only with food availability. Clearly, this reflects a physiological response to changing ecological conditions. Even subtle maternal responses during pregnancy, such as adjustment of blood flow to the uterus, fit a life-history model of reproductive optimization..$^{85,86}$

Other investment patterns also respond to ecological conditions. !Kung women have interbirth intervals of about four years. ${ }^{87}$ Because predators are prevalent, !Kung women who depend on bush foods carry a child at least occasionally until it is six years old. Blurton Jones, ${ }^{88,89}$ using a model of "backload" (the weight of a child plus foraged material), could predict interbirth intervals and mortality patterns. !Kung women living in compounds, who were not dependent on bush foods, had quite different schedules of births. The number of successful descendants was maximized for

\section{Today, a clearly negative correlation exists between a mother's job status or education and her lifetime fertility. This implies a conflict: what is invested in work cannot be invested in child care.}

bush-living women not by maximizing the rate of births, but by responding to the conflict between production of a new child versus the cost of that production in relation to the survival of other children. Again, looking for ecological constraints seems profitable.

Among the Ache ${ }^{33,90}$ and the Ye'kwana, ${ }^{91}$ nursing women can forage less than others. In some societies, these costs are partially defrayed by having other children assume responsibility for child care. The availability of peers or siblings to serve as caretakers can have an impact on a mother's lifetime fertility. On Ifaluk, for example, women whose first two children were girls had greater lifetime fertility than did others. ${ }^{92}$ Because daughters assist in child care on Ifaluk, mothers whose first children are daughters defray some costs.

In other societies, wet nurses were hired to defray these costs. A dramatic example is given by $\mathrm{Hrdy},{ }^{93}$ who found that interbirth interval, fertility, and infant mortality all varied with mothers' status. The richest women had very short interbirth intervals, very high fertility, and low infant mortality. A linear relationship between infant survival and the cost of wet nurses meant that the richest women, who could afford the best wet nurses, fared best. Among the bourgeois, complexities created greater variation in pattern. Poor women had longer interbirth intervals, lower fertility, and high infant mortality. Wet nurses fared worst of all, having long interbirth intervals, very low fertility, and very high infant mortality.

\section{Abortion, Infanticide, Abandonment, and Neglect}

Parental withdrawal of investment in their children seems at first obviously counter-selective. Within other species, including langurs and lions, it typically is not parents, but reproductive competitors (for example, males taking over a harem), who commit infanticide. ${ }^{94-98}$ Among primates, the overwhelming majority of infanticides are committed by immigrant males or males who do not belong to the victim's social group. ${ }^{99}$ Among humans, step-parents are more likely than parents to abuse or neglect children. ${ }^{100-102}$ Yet parents can commit infanticide, abortion, and abandonment. Because each infant requires a great investment, investment biases, ${ }^{54}$ even to the extent of infanticide, can be reproductively profitable. ${ }^{103}$ Selective reasons for canceling investment in a child include the mother's ability or inability to invest and her access to additional resources such as family or mate, as well as the child's ability to succeed. Other factors are the economic and reproductive value of older children or children who still may be born. Cross-culturally, deformed or seriously ill newborns are at greater risk for infanticide. ${ }^{103}$ Similarly, when circumstances such as too-close births, the birth of twins, or the absence of an investing man reduce a mother's chance of successful investment in a child, the likelihood is greater that she will neglect the child or kill it. ${ }^{103,104}$ Abortion, too, appears to be more common when the birth of an additional child is likely to reduce the mother's lifetime reproductive success. ${ }^{82,105}$ As women age and their reproductive value declines, termina- 
tion of investment is less likely. Even attitudes toward abortion in our society are related to the proportion of women in any group who are "at risk" of unwanted pregnancy. ${ }^{106}$

Historical studies of child abandonment indicate that a mother's ability to invest in a child has long been influenced by selective factors such as the mother's health, familial resources, and economic conditions as well as the child's health, legitimacy, and sex. During the eighteenth and nineteenth centuries in France, ${ }^{107}$ Spain, ${ }^{108}$ and Russia, ${ }^{109}$ child abandonment was related to economic factors and mother's abilities. Similarly, although he discerns no pattern, in Boswell's historical overview of child abandonment, $46 \%$ (29/63) of the cases he studied were related to maternal ability to invest, ${ }^{110}$ despite great variations in time, country, and other circumstances. When one considers resource allocation $(16 / 63 ; 25.5 \%)$ and offspring quality $(4 / 63 ; 6.3 \%)$, selective reasons were apparent in $49 / 63$ cases, or $77 \%$.

\section{Physiological Sex Biases: Trivers-Willard Effects}

In many polygynous species, including humans, male offspring are more expensive to raise than are female offspring: 65,111 they are carried longer in utero, are larger at birth, nurse more and more frequently, and are weaned later. Trivers and Willard ${ }^{111}$ argued that in polygynous species under these conditions females in good nutritional condition are more likely to bear sons than daughters. A more broadly applicable statement might be that when the reproductive success of one sex exceeds that of the other (as in elephant seals) or that when parental investment can influence the reproductive success of one sex but not the other (as in baboons), there should be a correlation between parental condition and investment in that sex..$^{23}$

Trivers and Willard assumed that mothers' physiological resources for successfully rearing offspring declines with age. In nonhuman species, as well as in many traditional human societies and developing countries, this is appropriate. Whenever the nutritional condition of mothers does not decline with age, a male bias in sex ratio may occur in older mothers. 36,112 In polygynous iteroparous species, if a female's condition is good, a bias toward bearing male offspring is predicted to be profitable as a female nears the end of her reproduction, to invest more heavily, with a greater potential reproductive profit if successful (e.g., male-biased sex ratios for older female gorillas ${ }^{113}$ ). In nineteenth-century Sweden, mothers over the age of 35 years showed a sex-ratio bias toward sons, while mothers under the age of 25 years bore more daughters. ${ }^{36}$ Such patterns underlie other influences such as parental sexpreference. ${ }^{114}$

\section{Other Familial Sex Biases}

Because resource control is an effective and widespread strategy for men in acquiring mates, ${ }^{29,115-117}$ resource inheritance biases are important; they can influence survivorship and the likelihood of reproduction. Perhaps no other species exhibits the same degree of resource transfer that can take place through inheritance within human families. Inheritance is frequently biased by legitimacy, birth order, and sex.

In societies with heritable goods, the size of a family and the sex of siblings may have somewhat different influences on men's and women's ability to marry at appropriate times. Within polygynous marital systems, inheritance is strikingly male-biased, ${ }^{118}$ which is precisely the pattern that would be predicted if reproductive success varies more for men than for women and if male success is influenced by resource control. In many societies, earlier-born sons tend to inherit the greatest proportion of family resources even when, as in nineteenth-century Sweden, more equal distribution is stipulated by law. For Swedish men, only the number of their brothers mattered with regard to their lifetime reproduction, suggesting that brothers compete for resources. In contrast, women's lifetime reproduction decreased as the number of their siblings increased. ${ }^{36}$ In many societies, as the total number of women's siblings increases, the more likely it is that the women will be drawn into caring for their siblings, re- gardless of their sex, at some cost to their own reproduction. Among fifteenth- and sixteenth-century Portuguese nobles, the proportion of never-married men and women decreased with birth order, as did the fertility of married individuals. ${ }^{119,120}$

In contemporary Tennessee, sons in higher-status families fare better than others. ${ }^{121}$ Among polygynous Mormons, sex-ratio and parental status are correlated as predicted by Trivers and Willard. ${ }^{122}$ Gaulin and Robbins ${ }^{123}$ have found a series of other TriversWillard effects in contemporary United States society. They examined interbirth intervals, birth weights, and the proportions of children nursed in relation to income and the presence of an adult male in the household. They found that as income increased, so did interbirth intervals and the percent of infants who were breast-fed-for sons, but not daughters. Indeed, on all seven of their measures, patterns differed for sons and daughters. In addition, daughters received relatively more from low-investment mothers, whereas sons received relatively more from high-investment mothers.

In many societies, a sex preference in infanticide exists; this represents a conundrum if it becomes widespread and persistent, for, as Fisher ${ }^{159}$ noted, the rare sex comes to be more valuable in any mating market. Dickemann ${ }^{124,125}$ found pertinent biases in sex preference in hypergynous societies. Because women may marry "up" and men "down," but the reverse is not allowed, daughters are valuable to lower-class families, but costly to upper-class families. Dickemann found that there was no single within-society sex bias, but that infanticide was female-biased in high-status families and that son preference was less strong in low-status families. These patterns, Dickemann argued, probably also represent a Trivers-Willard effect. It is possible, too, that otherwise rare male-biased infanticide occurred in high-status families. ${ }^{126}$

Voland ${ }^{127}$ examined the effect of father's status on children's survival in a nineteenth-century German parish. The overall sex ratio of children born was almost exactly even; the effect of mothers' age was not analyzed. Deaths during the first year of life as a 


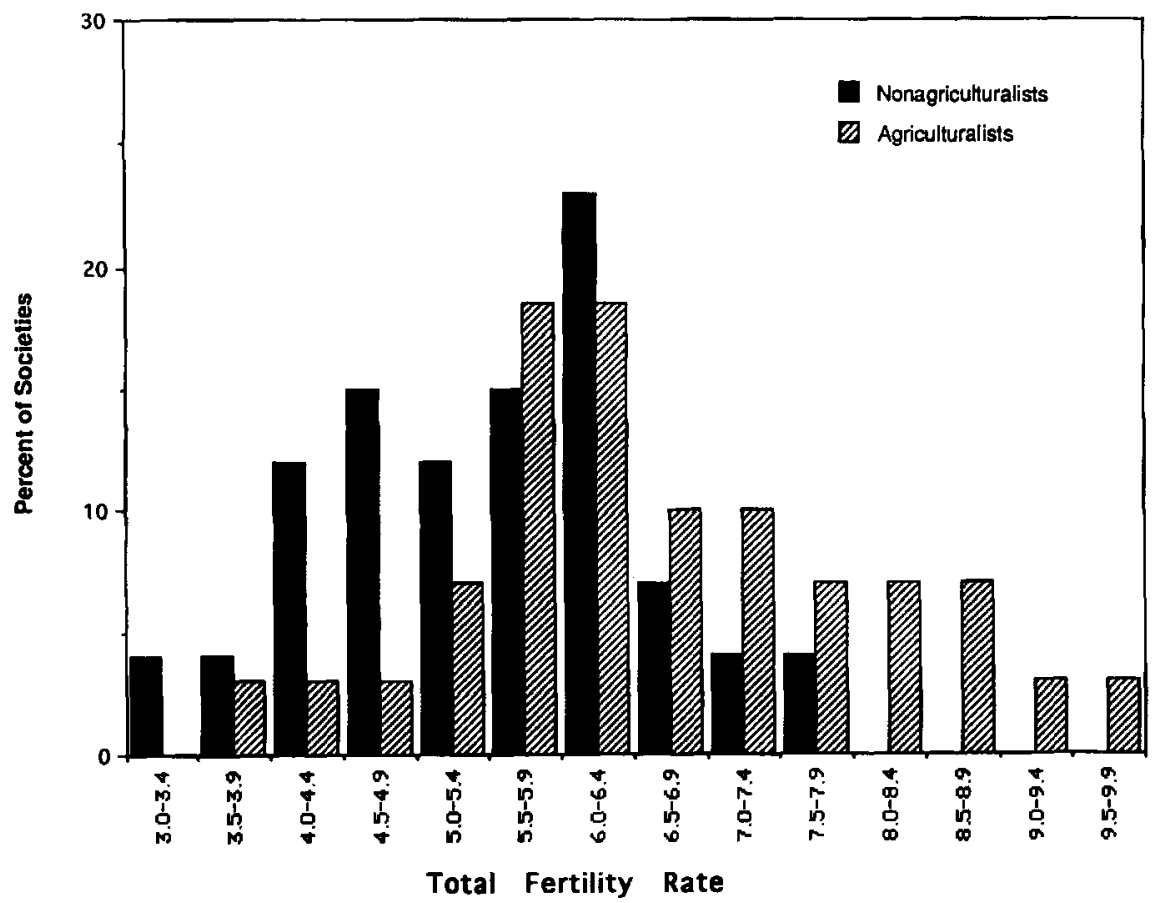

Figure 2 (modified from Bentley et al, 136). Natural (uncontrolled) fertility varies greatly among societies, with that among agricultural societies being higher than among forogers and horticulturalists ( $n=53$. Mann-Whitney U. $p=0.005$ ).

result of parental neglect were statusrelated: for farmers, daughters were likely to be considered less desirable than sons. ${ }^{40,128}$ For other classes, the reverse appeared to be true. Voland thus found evidence of uneven parental investment tied to the perceived value of each sex for parents in different classes.

\section{POPULATION OUTCOMES OF THE ECOLOGY OF FERTILITY}

If individual fertility is shaped by natural selection to respond to ecological conditions such as fluctuations in resources, then population patterns should be correlated with external conditions. We should be able to make sense of fertility patterns in noncontraceptive, "natural fertility" societies. We should find that the nineteenthcentury European fall in fertility, called "The" demographic transition, is in fact variable, and dependent on local resource conditions.

\section{Natural Fertility}

"Natural" fertility means simply that there is no evidence, either from historical documents or from starting, spacing, and stopping patterns, of conscious control of fertility within of-living indices, suggesting that individual fertility decisions responded to economic costs.

\section{Investment, Production, and Demographic Transitions}

Other things being equal, greater fertility means greater lineage success. But the cost of producing effective, competitive children-who survive, marry, and reproduce-is influenced by ecological conditions. Some conditions favor parents who shift their resources away from having more children and using them to increase their investment in existing children (Fig. 3). Unless there is a net increase in a family's total resources, the available resources must be allocated to fewer children. Under those circumstances, lower fertility fosters higher lifetime success. ${ }^{137,138}$ Thus, if parental resources can reduce child mortality or increase the likelihood that children will become well established and marry, the shifts in Figure 3B will be favored. Lower infant mortality, leading to increased population density, increased competitiveness, ${ }^{139}$, and industrialization are often cited as "causes" of demographic transition. Neither is necessary ${ }^{140}$ or sufficient to produce a decline in fertility. Numerous conditions can make it more expensive to produce effective, competitive children. ${ }^{14,38}$

Perhaps because of the costliness of children, individuals in modern societies make conscious decisions about fertility versus investment. Although accidental pregnancies complicate the picture, parents make deliberate decisions about family size in response to their judgment of available resources. ${ }^{141,142}$ When deliberately chosen family sizes are considered, income and family size are positively correlated. When income is judged as favorable relative to others, fertility is increased. $^{\text {141-143 }}$ Women on welfare ${ }^{64}$ clearly avoid further pregnancies in order to invest more effectively in their existing children. In fact, as Lancaster and Lancaster ${ }^{144}$ have argued, the perception of resources probably has influenced fertility decisions throughout human evolution.

This argument counts children as a net cost economically. What if, as some economic demographers ${ }^{19,145-147}$ argue, 
CETERIS PARIBUS

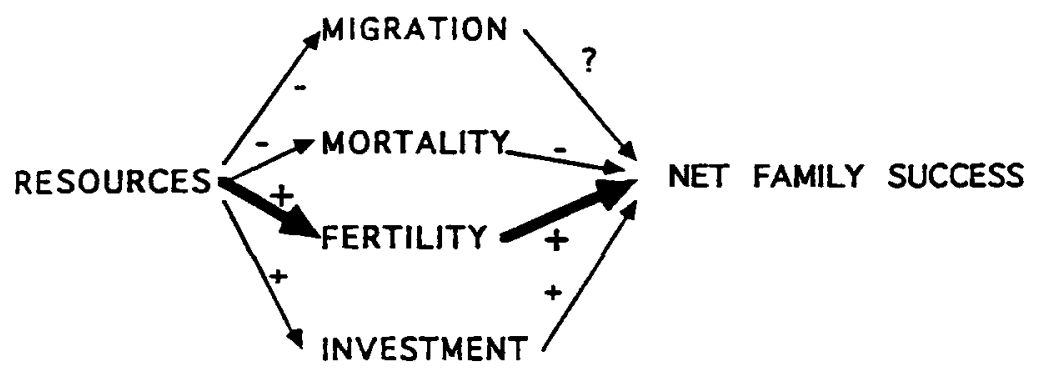

WHEN COMPETITION IS HARSH:

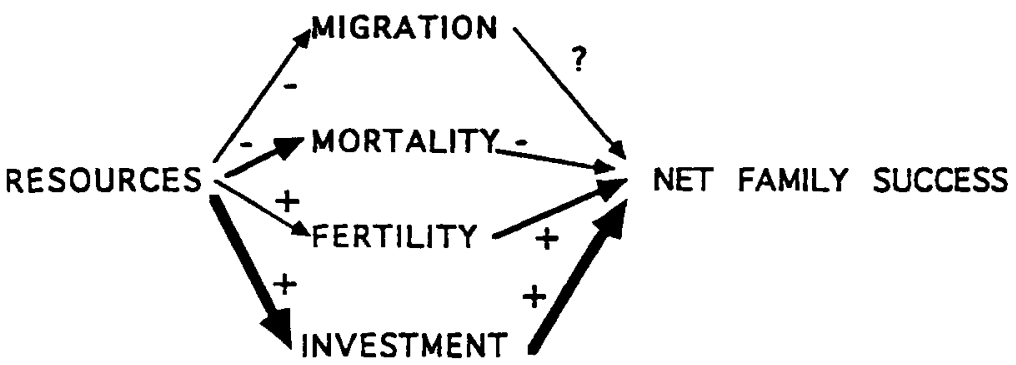

Figure 3. Other conditions equal, putting resources directly into fertility is the winning strategy. 112 Among mammals, this frequently means that males controlling more resources are able to mate with more females; it also means that more offspring can be provisioned. When conspecific competition is intense among offspring, parents may win by producing fewer, but better-invested. offspring. 14,139

children are a net economic gain for parents in pre- industrial and predemographic transition societies? So far, all analyses of actual data suggest that although the situation is complex, children's labor is never sufficient to result in a net economic gain to parents. ${ }^{143}$ Parents provide for their children, even in societies in which children work. Even grandparents provide for their grandchildren. Kin help each other, and, as Hamilton ${ }^{148}$ predicted, ${ }^{14,149}$ kin-helping tends to be preferential according to the degree of relatedness. Nonetheless, in situations in which children can defray some of their cost, 92 families may be larger.

An ecological approach to fertility, although it need not imply any conscious factors, is similar to the demographic models of individual decision and proximate variables, ${ }^{150-158}$ to Mosk's 159 "leveraging" approach to fertility, and to Crimmins and Easterlin's ${ }^{160,161}$ models of factors favoring a shift to conscious control of fertility. All have two important charac- teristics: they do not assume that all individuals are uniform and they entail an explicit trade-off between quantity and "quality" of children. The perceived nongenerality of some of these models may not be the consequence of flaws in the postulated relationships but of the difficulty of trying to explain patterns that are based, in part, on reproductive "decisions" by considering only the value of children in monetary (rather than lineage) terms.

Even this brief review suggests that, although there still is much to learn, evidence continues to accumulate that human fertility varies in nonrandom ways with ecological conditions. Recognizing such relationships seems to be the first step toward important functional refinements of the treatment of population patterns. In re-examining demographic models, considering not only monetary, but also reproductive, currencies may help resolve some previously perplexing fertility patterns. An additional ad- vantage, perhaps, is the insight from ecological demography that such models may, in fact, be very general, affecting all sexually reproducing organisms, and not particular to one or another society, or one or another currency. ${ }^{14}$

\section{ACKNOWLEDGMENTS}

As with any review paper, the work, comments, and criticisms of many people lie behind what appears. My thanks to Alice Clarke and Ken Lockridge, valuable colleagues, for collaborative work and repeated discussions, as well as to Debra Judge, Monique Borgerhoff Mulder, and Joel T. Heinen for helpful criticism. Comments on earlier papers by John Knodel, E. A. Wrigley, Roger Schofield, and John Caldwell, have again been helpful, although they may not be wholly in agreement with my arguments here. Elizabeth Shaw helped with historical analyses of child abandonment. Special thanks to Sarah Hrdy, both for the invitation to submit this manuscript, and for cogent, helpful criticism, especially on maternal allocation of effort. Thanks to John Fleagle for patient and expeditious editing.

\section{REFERENCES}

1 Wrigley EA, Schofield R (1981) The Population History of England 1541-1871. Cambridge: Harvard University Press.

2 Walkins SC (1989) The fertility transition: Europe and the third world compared. In Stycos JM (ed) Demography as an Interdiscipline, pp 27-55. New Brunswick: Transaction Publishers.

3 Coale AJ, Watkins SC (1986) The Decline of Fertility in Europe. Princeton: Princeton University Press.

4 Coleman D, Schofield R (eds) (1986) The State of Population Theory: Forward from Malthus. London: Basil Blackwell.

5 Schofield RS, Coleman D (1986) Introduction: The state of population theory. In Coleman D, Schofield R (eds) The State of Population Theory: Forward from Malthus, pp. 1-13. London: Basil Blackwell.

6 Lessells CM (1991) The evolution of life history strategies. In Krebs JR, Davies NB (eds) Behavioural Ecology, third edition. Oxford: Blackwell Scientific.

7 Cronk L (1991) Human behavioral ecology. Ann Rev Anthropol 20:25-53.

8 Borgerhoff Mulder M (1991) Human behavioral ecology. In Krebs JR, Davies NB (eds) Behavioural Ecology, third edition, pp 69-98. Oxford: Blackwell Scientific.

9 Smith EA (1992) Human behavioral ecology, part I. Evolutionary Anthropol 1:20-25. Part II, Evolutionary Anthropol 1:50-56.

10 Ellison P (1991) Reproductive ecology and human fertility. In Mascie-Taylor CGN, Lasker GW (eds) Applications of Biological Anthropology to Human Affairs, pp 14-54. Cam- 
bridge: Cambridge University Press. 11 Dawkins R (1989) The Selfish Gene. Oxford: Oxford University Press.

12 Alexander RD (1979) Darwinism and Human Affairs. Seattle: University of Washing ton Press.

13 Boyd R, Richerson PJ (1986) Culture and the Evolutionary Process. Chicago: University of Chicago Press.

14 Low B, Clarke AL, Lockridge K (1992) Toward an ecological demography. Population Development Review 18:1-31.

15 Kasarda JD, Billy JOG, West K (1986) Status Enhancement and Fertility: Reproductive Responses to Social Mobility and Educational Opportunity. New York: Academic Press.

16 Darwin C (1859) On the Origin of Species by Means of Natural Selection. Facsimile of the first edition with an introduction by Ernst Mayr. Cambridge: Harvard University Press. 17 Dupâquier J (1972) De l'animal à l'homme: Le mechanisme autorégulateur des populations traditionelles. Rev de L'Instit Sociol L'Université Libre Bruxelles 2:177-211.

18 Viazzo PP (1990) Upland Communities: Environment, Population, and Social Structure in the Alps Since the Sixteenth Century. Cambridge: Cambridge University Press.

19 Caldwell JC (1982) Theory of Fertility Decline. New York: Academic Press.

20 Hawkes K. Charnov EL (1988) Human fertility: Individual or group benefit? Curr Anthropol 20:469-471.

21 Botkin DB (1990) Discordant Harmonies: A New Ecology for the Twenty-first Century. Oxford: Oxford University Press.

22 Low B (1978) Environmental uncertainty and the parental strategies of marsupials and placentals. Am Naturalist 112:197-213.

23 Clutton-Brock TH (1991) The Evolution of Parental Care. Princeton: Princeton University Press.

24 Trivers RL (1972) Parental investment and sexual selection. In Campbell B (ed) Sexual Selection and the Descent of Man 18711971, pp 136-179. Chicago: Aldine.

25 Le Boeuf BJ, Reiter I (1988) Lifetime reproductive success in northern elephant seals. In Clutton-Brock TH (ed) Reproductive Success: Studies of Individual Variation in Contrasting Breeding Systems, pp 344-362. Chicago: University of Chicago Press.

26 Clutton-Brock TH, Guinness FE, Albon SD (1982) Red Deer: Behavior and Ecology of Two Sexes. Chicago: University of Chicago Press.

27 Irons W (1979) Cultural and biological success. In Chagnon NA and Irons W (eds) Evolutionary Biology and Human Social Behavior: An Anthropological Perspective. North Scituate MA: Duxbury Press.

28 Røskaft E, Wara A, Viken Å (1992) Reproductive success in relation to resource access and parental age in a small Norwegian farming parish during the period 1700-1900. Ethol Sociobiol 13:443-462.

29 Hill J (1984) Prestige and reproductive success in man. Ethol Sociobiol 5:77-95.

30 Borgerhoff Mulder M (1987) On cultural and biological success: Kipsigis evidence. Am Anthropol 89:617-634.

31 Borgerhoff Mulder M (1988a) Reproductive success in three Kipsigis cohorts. In Clutton- Brock TH (ed) Reproductive Success, pp 419-435. Chicago: University of Chicago Press.

32 Borgerhoff Mulder M (1988b) Kipsigis bridewealth payments. In Betzig L, Borgerhoff Mulder M, Turke P (eds) Human Reproductive
Behaviour: A Danwinian Perspective, pp 65-82. Cambridge: Cambridge University Press.

33 Hurtado M, Hill K, Kaplan H, Hurtado I. Tradeoffs between food acquisition and child care among Hiwi and Ache women. Hum Nature, in press.

34 Low B (1989) Occupational status and reproductive behavior in nineteeth-century Sweden: Locknevi Parish. Soc Biol 36:82101.

35 Low B (1990) Occupational status landownership and reproductive behavior in nineteenth-century Sweden: Tuna Parish. Am Anthropol 92:457-468.

36 Low B (1991) Reproductive life in nineteenth century Sweden: An evolutionary perspective on demographic phenomena. Ethol Sociobiol 12:411-448.

37 Low B, Clarke AL (1991) Family patterns in 19th century Sweden: Impact of occupational status and land ownership. J Fam History $16: 117-138$.

38 Low B, Clarke AL (1992) Resources and the life course. Ethol Sociobiol 13:463-494.

39 Low B, Clarke AL (1993) Historical perspectives on population and environment: Data from 19th century Sweden. In Ness G, Drake W, Brechen S (eds) Population-Environment Dynamics: Ideas and Observations. Ann Arbor: University of Michigan Press.

40 Low B, Clarke AL, Lockridge K (1991) Family Patterns in Nineteenth-Century Sweden: Variation in Time and Space. Demographic Database Monograph \#6. Umeå, Sweden.

41 Palmore JA, Gardner RW (1983) Measuring Mortality, Fertility, and Natural Increase: $A$ Self-Teaching Guide to Elementary Measures. Honolulu: East-West Population Institute, East-West Center.

42 Pfister U (1989) Proto-industrialization and demographic change: The Canton of $\mathrm{Zu}$ rich revisited. J Econ History 18:629-662.

43 Pfister U (1989) Work roles and family structure in proto-industrial Zurich. $\mathrm{I}$ Interdisc History 20:83-105.

44 Cronk L (1991) Wealth status and reproductive success among the Mukogodo of Kenya. Am Anthropol 932:345-360.

45 Fadiman JA (1982) An Oral History of Tribal Warfare: The Meru of Mt. Kenya. Athens OH: Ohio University Press.

46 Barkow JH (1977) Conformity to ethos and reproductive success in two Hausa communities: An empirical evaluation. Ethos 5:409-425.

47 Flinn MV (1986) Correlates of reproductive success in a Caribbean village. Hum Ecol 14:225-243.

48 Turke PW, Betzig LL (1985) Those who can do: Wealth status and reproductive success on Ifaluk. Ethol Sociobiol 6:79-87.

49 Kaplan H, Hill K (1985) Hunting ability and reproductive success among male Ache foragers: Preliminary results. Curr Anthropol 26:131-133.

50 Hill K, Kaplan H (1988) Tradeoffs in male and female reproductive strategies among the Ache. In Betzig L, Borgerhoff Mulder M, Turke PW (eds) Human Reproductive Behaviour: A Darwinian Perspective, pp 277-289 Cambridge: Cambridge University Press.

51 Chagnon NA (1979) Is reproductive success equal in egalitarian societies? In Chagnon NA, Irons W (eds) Evolutionary Biology and Human Social Behavior: An Anthropological Perspective. Boston: Duxbury.

52 Chagnon NA (1982) Sociodemographic attributes of nepotism in tribal populations: Man the rule-breaker. In Kings' College Sociobiology Group (eds) Current Problems in Sociobiology. Cambridge: Cambridge University Press.
53 Chagnon NA (1988) Life histories blood revenge and warfare in a tribal population. Science 239:985-992.

54 Hughes AL (1988) Evolution and Human Kinship. Oxford: University Press Oxford. 55 Hammel EA, Johansson S, Gunsberg C (1983) The value of children during industrialization: Sex ratios in childhood in nineteenth-century America. J Fam History (Winter):400-417.

56 Cain $M$ (1985) On the relationship between landholding and fertility. Popul Studies 39:5-15.

57 McInnis RM (1977) Childbearing and land availability: Some evidence from individual household data. In Lee $\mathrm{R}$ (ed) Population Patterns in the Past, pp 201-227. New York: Academic Press.

58 Hayami A (1980) Class differences in marriage and fertility among Tokugawa villagers in Mino Province. Keio Econ Studies 17:1-16. 59 Hughes AL (1986) Reproductive success and occupational class in eighteenth-century Lancashire England. Soc Biol 33:109-115.

60 Voland E (1990) Differential reproductive success within the Krummhörn population (Germany 18th and 19th centuries). Behav Ecol Sociobiol 26:65-72.

61 Birdsall N (1980) Population growth and poverty in the developing world. Popul Bull 35:3-46.

62 Vining DR (1986) Social versus reproductive success: The central theoretical problem of human sociobiology. Behav Brain Sci 9:167-216.

63 Mueller U (1991) Social and reproductive success. Theoretical considerations and a case study of the West Point Class of 1950. ZUMA: Zentrum für Umfragen, Methoden und Analysen.

64 Rank MA (1989) Fertility among women on welfare: Incidence and determinants. Am Sociol Rev 54:296-304.

65 Daly M, Wilson M (1983) Sex Evolution and Behavior. second edition. Boston: Willard Grant Press.

66 Pérusse D (1992) Cultural and reproductive success in industrial societies: Testing the relationship at the proximate and ul timate levels. Behav Brain Sci

67 Fisher RA (1958) The Genetical Theory of Natural Selection, second revised edition. New York: Dover.

68 Keyfitz N (1985) Applied Mathematical Demography, second edition. New York: Springer-Verlag.

69 Murdock GP (1981) Atlas of World Cultures. Pittsburgh: University of Pittsburgh Press.

70 Drake M (1969) Population and Society in Norway: 1735-1865. Cambridge: Cambridge University Press.

71 Knodel J (1981) Remarriage and marital fertility in Germany during the eighteenth and nineteenth centuries: An exploratory analysis based on German village genealogies. In Dupaquier $J$, Helin $E$, Laslett $P$, Livi-Bacci $M$ (eds) Marriage and Remarriage in Past Populations. New York: Academic Press.

72 Knodel J, Lynch KA (1985) The decline of remarriage: Evidence from German village populations in the eighteenth and nineteenth centuries. J Fam History 10:34-59.

73 Imhof AE (1981) Remarriage in rural populations and in urban middle and upper strata in Germany from the sixteenth to the twentieth century. In Dupâquier J, Hélin JE, Laslett P, Livi-Bacci M, Sogner S (eds) Marriage and Remarriage in Populations of the Past, pp 335-346. New York: Academic Press. 
74 Bideau A (1980) A demographic and social analysis of widowhood and remarriage: The example of the Castellany of Thoissey-enDombes 1670-840. J Fam History 5:28-43. 75 Wolf AP (1981) Women widowhood and fertility in pre-modern China. In Dupâquier J, Hélin E, Laslett P, Livi-Bacci M, Sogner S(eds) Marriage and Remarriage in Populations of the Past, pp 139-147. New York: Academic Press. 76 Åkerman S (1981) The importance of remarriage in the seventeenth and eighteenth centuries. In Dupâquier J, Hélin E, Laslett P, Livi-Bacci M, Sogner S (eds) Marriage and Remarriage in Populations of the Past, pp 163175. New York: Academic Press.

77 Cabourdin G (1981) Le remariage en France sous l'ancien régime (seizièmedix-huitième siècles). In Dupâquier J. Hélin E, Laslett P, Livi-Bacci M, Sogner S (eds) Marriage and Remarriage in Populations of the Past, pp 273 285. New York: Academic Press.

78 Corsini CA (1981) Why is remarriage a male affair? Some evidence from Tuscan villages during the eighteenth century. In Dupâquier J, Hélin E, Laslett $P$, Livi-Bacci $M$, Sogner $S$ (eds) Marriage and Remarriage in Populations of the Past, pp 385-395. New York: Academic Press.

79 Bideau A, Perrenoud A (1981) Remariage et fécondité. Contribution à l'étude des mécanismes de récuperation des populations anciennes. In Dupâquier $J$, Hélin $E$, Laslett $P$, Livi-Bacci M, Sogner S (eds) Marriage and Remarriage in Populations of the Past, pp 547559. New York: Academic Press.

80 Griffith JD (1980) Economy family and remarriage. Theory of remarriage and application to preindustrial England. J Fam Iss : 479-496.

81 Glick PC, Lin S-L (1986) Recent changes in divorce and remarriage. J Marriage Fam 48:737-747.

82 Hill E, Low B (1991) Contemporary abortion patterns: A life-history approach. Ethol Sociobiol 13:35-48.

83 Blurton Jones N (1989) The costs of children and the adaptive scheduling of births: Towards a sociobiological perspective on demography. In Rasa A, Vogel C, Voland E (eds) Sexual and Reproductive Strategies. Kent: Croom Helm.

84 Bailey RC, Jenike MR, Ellison PT, Bentley GR, Harrigan AM, Peacock NR (1992) The ecology of birth seasonality among agriculturalists in central Africa. J Biosoc Sci, in press.

85 Peacock N (1990) Comparative and cross-cultural approaches to the study of human female reproductive failure. pp 195-220 in Rousseau CJ (ed) Primate Life History and Evolution. New York: Wiley-Liss.

86 Peacock N (1991) An evolutionary perspective on the patterning of maternal investment in pregnancy. Hum Nature 2:351-385. 87

88 Blurton Jones N (1986) Bushman birth spacing: a test for optimal interbirth intervals. Ethol Sociobiol 7:91-105.

89 Blurton Jones N (1987) Bushman birth spacing: Direct tests of some simple predic tions. Ethol Sociobiol 8:183-203.

90 Hurtado M, Hawkes K, Hill K (1985) Female subsistence strategies among Ache hunter-gatherers of eastern Paraguay. Hum Ecol 13:1-28.

91 Hames RB (1988) The allocation of parental care among the Ye'kwana. In Betzig L, Borgerhoff Mulder M. Turke P (eds) Human Reproductive Behaviour: A Darwinian Perspective. Cambridge: Cambridge University Press. 92 Turke PW (1988). Helpers at the nest:
Childcare networks in Ifaluk. In Betzig L, Borgerhoff Mulder M, Turke P (eds) Human Reproductive Behaviour: A Darwinian Perspective. Cambridge: Cambridge University Press.

93 Hrdy SB (1992) Fitness tradeoffs in the history and evolution of delegated mothering with special reference to wet-nursing abandonment and infanticide. Ethol Sociobiol 13:409-442.

94 Hrdy SB (1974) Male-male competition and infanticide among the lemurs (Presbytis entellus) of Abu Rajasthan. Folia Primatol 22:19-58.

95 Hrdy SB (1978) Allomaternal care and the abuse of infants among Hanuman langurs. In Chivers DJ, Herbert P (eds) Recent Advances in Primatology, Vol. 1. New York: Academic Press.

96 Hrdy SB (1979) Infanticide among animals: A review classification and implications for the reproductive strategies of females. Ethol Sociobiol 1:13-40.

97 Packer C, Pusey AE (1983) Adaptations of female lions to infanticide by incoming males. Am Naturalist 121:716-728.

98 Packer C, Pusey AE (1984) Infanticide in carnivores. In Hausfater G, Hrdy SB (eds) Infanticide: Comparative and Evolutionary Perspectives. New York: Aldine.

99 Struhsaker TT, Leland, L (1986) Colob ines: Infanticide by adult males. In Smuts BB, Cheney DL, Seyfarth RM, Wrangham RW Struhsaker TT (eds) Primate Societies, pp 8398. Chicago: University of Chicago Press.

100 Daly M, Wilson M (1984) A sociobiological analysis of human infanticide. In Hausfater G, Hrdy SB (eds) Infanticide Comparative and Evolutionary Perspectives, pp 487-502. New York: Aldine.

101 Daly M, Wilson M (1985) Child abuse and other risks of not living with both parents. Ethol Sociobiol 6:197-210.

102 Daly M, Wilson M (1987) Children as homicide victims. In Gelles RJ, Lancaster JB (eds) Child Abuse and Neglect: Biosocial Dimensions, pp 201-214. New York: Aldine.

103 Daly M, Wilson M (1988) Homicide. Hawthorn NY: Aldine de Gruyter.

104 Bugos PE, McCarthy LM (1984) Ayoreo infanticide: A case study. In Hausfater G, Hrdy SB (eds) Infanticide: Comparative and Evolutionary Perspectives, pp 503-520. NY: Aldine. 105 Torres A, Forrest JD (1988) Why do women have abortions? Fam Planning Perspect 20:169-176.

106 Betzig LB, Lombardo LH (1991) Who's pro-choice and why. Ethol Sociobiol 13:49-71 107 Fuchs R (1984) Abandoned Children: Foundlings and Child Welfare in Nineteenth Century France. Albany: SUNY Press.

108 Sherwood J (1988) Poverty in EighteenthCentury Spain: Women and Children of the Inclusa. Toronto: University of Toronto Press.

109 Ransel D (1988) Mothers in Misery: Child Abandonment in Russia. Princeton: Princeton University Press.

110 Boswell J (1990) The Kindness of Strangers: The Abandonment of Children in Western Europe from Late Antiquity to the Renaissance. New York: Vintage Press.

111 Trivers RL, Willard DE (1973) Natural selection of parental ability to vary the sex ratio. Science 179:90-92.

112 Williams GC (1966) Adaptation and Natural Selection. Princeton: Princeton University Press.

113 Mace GM (1990) Birth sex ratio and infant mortality rates in captive western lowland gorillas. Folia Primatol 55:156-165.
114 Knodel J (1988) Demographic Behavior in the Past: German Village Populations in the 18 th and 19th Centuries. Cambridge: Cambridge University Press.

115 Betzig LB (1986) Despotism and Differential Reproductive Success: A Darwinian View of Human History. Chicago: Aldine.

116 Flinn MV, Low BS (1986) Resource distribution social competition and mating patterns in human societies. In Rubenstein D, Wrangham R (eds) Ecological Aspects of Social Evolution, pp 217-243. Princeton: Princeton University Press.

117 Low B (1990) Sex, power and resources: Ecological and social correlates of sex differences. Int J Contemp Sociol 27:49-73.

118 Hartung J (1982) Polygyny and inheritance of wealth. Curr Anthropol 23:1-12.

119 Boone JL III (1986) Parental investment and elite family structure in preindustrial states: A case study of late medieval-early modern Portuguese genealogies. Am Anthropol 88:859.

120 Boone JL III (1988) Parental investment social subordination and population processes among the 15 th and 16th century Portuguese nobility. In Betzig L, Borgerhoff Mulder M, Turke P (eds) Human Reproductive Behaviour: A Darwinian Perspective, pp 201220. Cambridge: Cambridge University Press. 121 Abernethey V, Yip R (1990) Parent characteristics and sex differential infant mortality: The case in Tennessee. Hum Biol 62:279-290.

122 Mealey L, Mackey W (1990) Variation in offspring sex ratio in women of differing social status. Ethol Sociobiol 11:83-95.

123 Gaulin SJC, Robbins CJ (1991) TriversWillard effect in contemporary North American society. Am J Phys Anthropol 85:61-68.

124 Dickemann M (1979) Female infanticide, reproductive strategies, and social stratification: A preliminary model. In Chagnon NA, Irons W (eds) Evolutionary Biology and Human Social Behavior: An Anthropological Perspective. North Scituate MA: Duxbury Press.

125 Dickemann M (1981) Paternal confidence and dowry competition: A biocultural analysis of purdah. In Alexander RD Tinkle DW (eds) Natural Selection and Social Behavior. New York: Chiron Press.

126 Parry JP (1979) Caste and Kinship in Kangara. London: Routledge \& Paul.

127 Voland E (1984) Human sex-ratio manipulation: Historical data from a German parish. J Hum Evol 13:99-107.

128 Johansson SR (1987) Status anxiety and demographic contraction of privileged populations. Popul Dev Rev 13:439-470.

129 Henry L (1961) Some data on natural fertility. Soc Biol 8:81-91.

130 Knodel J (1983) Natural fertility: Age patterns levels and trends. In Bulatao RA, Lee RD (eds) Determinants of Fertility in Developing Countries, Vol. I. Supply and Demand For Children, pp 61-102. New York: Academic Press.

131 Wrigley EA (1978) Fertility strategy for the individual and the group. In Tilly C (ed) Historical Studies of Changing Fertility, pp 135-154. Princeton: Princeton University Press.

132 Coale AJ, Trussell TJ (1974) Model fertility schedules: Variations in the age structure of childbearing in human populations. Popul Index 40:185-258 (see also Erratum, Popul In$\operatorname{dex} 41: 572$ )

133 Coale AJ, Trussell TJ (1978) Technical note: Finding the two parameters that specify a model schedule of fertility. Popul Index 44:203-213. 
134 Wilson C, Oeppen J, Pardoe M (1988), What is natural fertility? The modelling of a concept. Popul Index 84:4-20.

135 Campbell KL, Wood JW (1988) Fertility in traditional societies. In Diggory P, Potts M Teper S (eds) Natural Human Fertility: Social and Biological Determinants, pp 39-69. London: Macmillan Press in cooperation with The Eugenics Society.

136 Bentley GR, Goldberg T, Jasienska. G (1992) The fertility of agricultural and non-agricultural traditional societies. Working Paper No. 1992-02, Population Issues Research Center, Pennsylvania State University, 22 Burrowes Bldg, University Park, PA.

137 Rogers AR (1990) The evolutionary economics of human reproduction. Ethol Sociobiol 11:479-495.

138 Rogers AR (1991) Conserving resources for children. Hum Nature 2:73-82.

139 MacArthur RH, Wilson EO (1967) The Theory of Island Biogeography. Princeton: Princeton University Press.

140 Knodel J, Havanon N, Sittitrai W (1990) Family size and the education of children in the context of rapid fertility decline. Popul Dev Rev 16:31-62.

141 Freedman DS, Thornton A (1982) Income and fertility: the elusive relationship. Demography 19:65-78.

142 Johnson NE, Lean S (1985) Relative income race and fertility. Popul Studies 39:99112.

143 Turke PW (1989) Evolution and the demand for children. Popul Dev Rev 151:61-90. 144 Lancaster JB, Lancaster CS (1987) The watershed: Change in parental-investment and family-formation in the course of human evolution. In Lancaster JB, Altman J, Sherrod AS (eds) Parenting Across the Life Span: Biosocial Dimensions, pp 187-205. New York: Aldine de Gruyter.

145 Caldwell JC (1976) Toward a restatement of demographic transition theory. Popul Dev Rev 2:321-366.

146 Caldwell JC (1983) Direct economic costs and benefits of children. In Bulatao RA Lee RD (eds) Determinants of Fertility in Developing Countries, Vol 1, pp 458-493. NY: Academic Press.

147 Handwerker WP (1986) Culture and re production: Exploring micro/macro linkages. In Handwerker WP (ed) Culture and Reproduction: An Anthropological Critique of Demographic Transition Theory. Boulder: Westview Press.

148 Hamilton WD (1964) The genetical evolution of social behavior. I, II. J Theoret Biol $7: 1-52$.

149 Turke PW (1992) Theory and evidence on wealth flows and old-age security: A reply to Fricke. Popul Dev Rev 17:687-702.

150 Becker G (1981) A Treatise On The Family. Cambridge: Harvard University Press.

151 Becker G, Lewis HG (1974) Interaction between quantity and quality of children. In Schultz TW (ed) Economics of the Family: Marriage Children and Human Capital, pp 8190. Chicago: Chicago University Press.

152 Easterlin R (1978) The economics and sociology of fertility: A synthesis. In Tilly $C$ (ed) Historical Studies of Changing Fertility, pp
57-134. Princeton: Princeton University Press.

153 Tilly $C$ (1978) The historical study of vital processes. In Tilly C (ed) Historical Studies of Changing Fertility, pp 1-55. Princeton: Princeton University Press.

154 Bongaarts J (1978) A framework for analyzing the proximate determinants of fertility. Popul Dev Rev 4:105-132.

155 Bongaarts $\mathrm{J}$ (1982) The fertility inhibiting effects of the intermediate fertility variables. Studies Fam Planning 13:179-189.

156 Lindert PH (1978) Fertility and Scarcity in America. Princeton: Princeton University Press.

157 Lesthaeghe R, Wilson C (1986) Modes of production secularization and the pace of the fertility decline in western Europe 1870-1930. In Coale AJ, Watkins S (eds) The Decline of Fertility in Europe. Princeton: Princeton University Press.

158 Simon J (1974) The Effect of Income on Fertility. Carolina Population Center Monograph 19. North Carolina: Chapel Hill.

159 Mosk C (1983) Patriarchy and Fertility: Japan and Sweden 1880-1960. New York: Academic Press.

160 Crimmins EM, Easterlin RA (1984) The estimation of natural fertility: A micro approach. Soc Biol 31:160-170.

161 Easterlin R, Crimmins E (1985) The Fertility Revolution: A Supply-Demand Analysis. Chicago: University of Chicago Press.

(c) 1993 Wiley-Liss, Inc.
Evolutionary Anthropology is a review journal focusing on current issues in biological anthropology, archeology, primatology, human ecology, and other areas pertinent to understanding human evolution in its broadest sense. It is designed to provide researchers, educators, and students in anthropology and related disciplines with current summaries of recent research results, views on theoretical issues, and discussion of changing perspec- tives in a concise, readable format. Articles in Evolutionary Anthropology are commissioned by the Editor in conjunction with the Associate Editors and are subject to review prior to acceptance and publication. However, potential authors who wish to contribute either News articles or Review articles may contact either the Editor or an appropriate Associate Editor to discuss possible contributions. 